Rhine terrace $[9,10]$ although the normal magnetic polarity of the lava (fluxgate field measurements) suggest the age of the lava to be younger than $0.73 \mathrm{Ma}$ using the most recent paleomagnetic time scale [11]. Unresolved discrepancies between the high ages of lavas Hohe Buche (East-Eifel) and Sarresdorf (West-Eifel) overlying low terraces (Niederterrassen) believed to be younger than 0.1 Ma may be due to excess argon. Ultramafic nodules may be the reason for the anomalously high age of the Ruderbusch lava overlying the Kyll middle terrace [10], whose age may be only about half that suggested by the present $\mathrm{K} / \mathrm{Ar}$ data.

Oligocene ages of two Tertiary alkali basalts in the East-Eifel extend the area of previously established Oligocene volcanism eastwards [12]. The Miocene age of Arensberg volcano is identical to that found earlier [12]. Middle Tertiary volcanism in the Eifel may have occurred in distinct Oligocene and Miocene phases. The new data corroborate previous suggestions that the postulated Eifel plume [13] is not supported by age data $[12,14]$.

The age distribution of Quaternary volcanic activity in both East- and West-Eifel does not indicate termination of volcanic activity. Magma and thus heat transfer from the mantle to the crust may still continue.

The K/Ar determinations were carried out by Amdel Laboratories. We thank the
Deutsche Forschungsgemeinschaft, the Bundesministerium für Forschung und Technologie and the European Commission in Brussels for support of our work.

\section{Received October 25, 1979}

1. Frechen, J., Lippolt, H.-J.: Eiszeitalter Gegenwart 16, 5 (1965)

2. Lanphere, M.A., Dalrymple, G.B. : Am. J. Sci. (in press)

3. Windheuser, H., Brunnacker, K.: Geol. Jb. Hessen 106, 261 (1978)

4. Frechen, J., Heide, H.: Decheniana 122, 35 (1969)

5. Frechen, J.: Siebengebirge am Rhein Laacher Vulkangebiet - Maargebiet der Westeifel, Samml. Geol. Führer, Vol. 56. Stuttgart: Bornträger 1976

6. Quitzow, H.: Centenaire Soc. Geol. Belgique l'Evol. Quaternaire des bassins fluviaux de la mer du Nord Meridionale 1974, 53

7. Negendank, J.F.W.: N. Jb. Geol. Palâont. Mh. 1977, 532

8. Lorenz, V., Büchel, G.: Nachr. Dtsch. Geol. Ges., H. 19, 30 (1978)

9. Zepp, J.: Verh. Naturhist. Ver. Rheinld. Westf. 90, 1 (1933)

10. Gebhardt, I.: Decheniana 115,143 (1963)

11. Mankinen, E.A., Dalrymple, G.B.: J. Geophys, Res. 84,615 (1979)

12. Cantarel, P., Lippolt, H.J.: N. Jb. Geol. Paläont. Mh. 1977,600

13. Duncan, R.A., Petersen, N., Hargraves, R.B.: Nature 239, 82 (1972)

14. Duda, A., Schmincke, H.-U.: N. Jb. Min. Abh. 132, 1 (1978)

\title{
Formation of Long-Chain Carbon Molecules in Interstellar Space
}

\section{H.D. Breuer and H. Petry}

Institut für Physikalische Chemie der Universität des Saarlandes, D-6600 Saarbrücken

Long-chain hydrocarbon molecules are supposed to be constituents of interstellar gas [1]. Through their absorption bands, these molecules may give rise to the diffuse interstellar lines [2]. They are proposed to be formed by ion-molecule reactions starting with $\mathrm{C}^{+}+\mathrm{H} \rightarrow \mathrm{CH}^{+}$and further addition of other atoms or radicals [1]. However, this mechanism is somewhat unsatisfactory for molecules like $\mathrm{HC}_{9} \mathrm{~N}$ [3] or $\mathrm{C}_{4} \mathrm{H}$ [4]. We therefore suggest another mechanism for the formation of this kind of molecule: carbon chains consisting of two or more carbon atoms are blown away from carbon stars. Due to temperature and radiation conditions or due to the interstellar radiation field, these particles may be ionized. By collisions with other atoms the observed molecules or radicals or hydrocarbons can be formed.

To test this mechanism we performed an experiment in which carbon chains could be produced under UHV conditions without interference from any other gas. By an electric explosion of very thin graphite fibers $(7 \mu \mathrm{m})$ in a hydrogen atmosphere, $\mathrm{C}, \mathrm{C}_{2}$, and $\mathrm{C}_{3}$ could be detected in a timeof-flight mass spectrometer (Table 1). In
Table 1. Explosion products. The masses marked by an asterisk are partly masked by peaks from the residual gas

\begin{tabular}{llllll}
\hline$\frac{\mathrm{m}}{\mathrm{e}}$ & & $\frac{\mathrm{m}}{\mathrm{e}}$ & & $\frac{\mathrm{m}}{\mathrm{e}}$ & \\
\hline 12 & $\mathrm{C}^{+}$ & 24 & $\mathrm{C}_{2}^{+}$ & 36 & $\mathrm{C}_{3}^{+}$ \\
13 & $\mathrm{CH}^{+}$ & 25 & $\mathrm{C}_{2} \mathrm{H}^{+}$ & 37 & $\mathrm{C}_{3} \mathrm{H}^{+}$ \\
14 & $\mathrm{CH}_{2}^{+}$ & 26 & $\mathrm{C}_{2} \mathrm{H}_{2}^{+}$ & 38 & $\mathrm{C}_{3} \mathrm{H}_{2}^{+}$ \\
15 & $\mathrm{CH}_{3}^{+}$ & 27 & $\mathrm{C}_{2} \mathrm{H}_{3}^{+}$ & 39 & $\mathrm{C}_{3} \mathrm{H}_{3}^{+}$ \\
$16^{*}$ & $\mathrm{CH}_{4}^{+}$ & $28^{*}$ & $\mathrm{C}_{2} \mathrm{H}_{4}^{+}$ & $40^{*}$ & $\mathrm{C}_{3} \mathrm{H}_{4}^{+}$ \\
& & 29 & $\mathrm{C}_{2} \mathrm{H}_{5}^{+}$ & 41 & $\mathrm{C}_{3} \mathrm{H}_{5}^{+}$ \\
& 30 & $\mathrm{C}_{2} \mathrm{H}_{6}^{+}$ & 42 & $\mathrm{C}_{2} \mathrm{H}_{6}^{+}$ \\
& & & 43 & $\mathrm{C}_{2} \mathrm{H}_{7}^{+}$ \\
& & & & $44^{*}$ & $\mathrm{C}_{2} \mathrm{H}_{8}^{+}$ \\
\hline
\end{tabular}

some experiments $C_{4}$ has also been observed but its abundance was only just above the detection limit of our instruments. Optical spectra of the explosion indicate that the carbon was almost completely ionized.

The mass spectra are markedly different from the fragmentation patterns of $\mathrm{CH}_{4}$, $\mathrm{C}_{2} \mathrm{H}_{6}$, and $\mathrm{C}_{3} \mathrm{H}_{8}$. So the hypothesis that the observed products are formed in the ion source of the mass spectrometer can be excluded.

Using nitrogen instead of hydrogen, only $\mathrm{CN}, \mathrm{C}_{2} \mathrm{~N}$, and $\mathrm{C}_{2} \mathrm{~N}_{2}$ have been detected so far. The product yield is much smaller than in the case of hydrogen. This may be due to the higher dissociation energy of nitrogen.

The results of our experiments indicate that molecules or radicals containing more than two carbon atoms can be formed in reactions in which atoms are added to carbon chains. Especially in the case of longer chains, the reaction probability is greatly enhanced over the multi-step ion-molecule reactions. Even a radical as small as $\mathrm{C}_{4} \mathrm{H}$ can be formed four times faster by adding a hydrogen atom to $C_{4}$ than by the successive reaction of a carbon ion with a hydrogen atom and three carbon atoms or ions.

The financial assistance of the Deutsche Forschungsgemeinschaft is kindly acknowledged.

\section{Received August 30, 1979}

1. Mitchell, G.F., Huntress, W.T. : Nature 278 , 722 (1979)

2. Hoyle, F., Wickramasinghe, N.C.: ibid. 266 , $241(1977)$

3. Broten, N.W., et al.: Astrophys. J. 223, L 105 (1978)

4. Guélin, M., Green, S., Thaddeus, P.: ibid. 224, L 27 (1978) 